\title{
口蓋扁桃悪性腫瘍の統計的観察
}

\author{
西岡 博之・三吉 康郎 - 坂倉 康夫 ·三井 洋 \\ 福喜多 啓三・松原 隆志・堀 みどり
}

\section{A Clinical Examination of Malignant Tumor of the Palatine Tonsil}

\author{
A 20-year survey \\ Hiroyuki Nishioka, Yasuro Miyoshi, Yasuo Sakakura, Hiroshi Mitsui, \\ Keizo Fukukita, Takashi Matsubara and Midori Hori \\ (Mie University)
}

From 1961 to 1980,45 patients with malignant tumor of the palatine tonsil were treated at the Department of Otolaryngology, Mie University Hospital. Of these, 12 patients were cancer and 33 sarcoma.

Tonsillar cancer predominantly affected the male, whereas sarcoma was found in the male and female almost equally. The age distribution of tonsillar cancer was uniform, while there were two peaks in the fourth and seventh decades of life for tonsillar sarcoma. Eighty-three percent of cancer was squamous cell carcinoma, and all the sarcoma cases were malignant lymphoma of which $94 \%$ were reticulum cell sarcoma. Seventy-five percent of carcinoma were stage III or IV, while $94 \%$ of malignant lymphoma were stage I or II at the time of diagnosis. Sore throat was the most commonly encountered chief complaint for both carcinoma and malignant lymphoma. Three patients $(25 \%)$ of those with carcinoma and four $(12 \%)$ malignant lymphoma patients complained of a lump in the neck.

All the patients with tonsillar malignancy underwent radiation therapy, and chemotherapy was also used in nine patients $(75 \%)$ with carcinoma and $19(58 \%)$ with malignant lymphoma. Crude survival rates for tonsillar cancer was $64 \%$ for 1 year, $20 \%$ for 2 years, $11 \%$ for 3 years and $0 \%$ for 5 years, and for malignant lymphoma of the palatine tonsil it was $45 \%$ for 1 year, $40 \%$ for 2 years, $37 \%$ for 3 years and $22 \%$ for 5 years.

Although both carcinoma and malignant lymphoma had poor prognosis in this study, the preliminary results of combined radiation and chemotherapy for malignant lymphoma were encouraging. It was found that the total radiation dose of 5,000 7,000 rads for carcinoma and $4,000 \sim 6,000$ rads for malignant lymphoma of the palatine tonsil was satisfactory in this study. 


\section{I 緒言}

扁桃由来の腫瘍は，その大半が悪性腫瘍で，主に口蓋扁桃に発生し，発生頻度は低いとされてい る ${ }^{1) 3)}$. しかし，口蓋扁桃悪性腫瘍は，必ずしも稀なものではないとする意見4）あり，特に，扁 桃に発生する癌腫は，喉頭に発生する癌腫とほぼ同等の発生頻度を持つとする報告5)6) もる。.

口蓋扁桃悪性腫瘍を大別すると，上皮性，非上皮性に分類でき，前者は扁平上皮癌，後者は悪性 リンパ腫がその代表的組織型で，移行上皮癌やリンパ上皮腫を扁平上皮癌より独立させ分類するこ とも多(113)4).

近年，診断法及び治療法の発展により，口蓋扁桃悪性腫瘍に対し，種々の治療法が試みられてい るが，未だ統一的見解のないのが実情である。

今回我々は, 1961年 1 月から1980年12月までの 20 年間に, 当教室にて入院加療した口蓋扁桃悪性 腫瘍患者 45 名に対し, 年令分布, 病理組織学的分類, 主訴, 来院までの期間, 治療法, 予後などに ついて統計的観察を行ったので，若干の考察を加え報皆する.

\section{II 対象及び分類}

1961年 1 月より1980年末むでに，三重大学医 学部耳鼻咽喉科にて入院加療を行った口蓋扁桃 覀性腫瘍の新鮮例45名を対象とした。これは, 全咽頭悪性腫瘍患者の $21 \%$ 占めている.
癌腫については, 1978年 UICCによる TNM 及び Stage 分類》をを, 又, 悪性りンパ腫につ いては, Ann Arbor ${ }^{8)} の$ Hodgikin 病病期分 類に準じて Stage 分類を行った.

\section{III 癌腫について}

口蓋扁桃悪性腫瘍のらち, 癌腫は, 男子が 12 例中10例 $(83 \%)$ を占め, 圧倒的に多く，その 年令分布をみると, 症例数が少ないものの, 癌 年令に好発する傾向にあった（表 1 及び図 1 ）.

病理組織学的分類では, 癌腫の殆んどが扁平 上皮癌で，12例中 10 例（83\%）を占め，その 他, 男子に, 移行上皮癌 1 例, リンパ上皮腫 1 例がみられた（表 2 ）.

Stage 分類を行らと, 表 3 に示す如くで, Stage I が 1 例, Stage II が 2 例と, Stage I , II を併せても全体の $25 \%$ で, 早期例が非常 に少なく, Stage III, N が計 9 例（75\%）で大

表 1 口蓋扁桃悪性腫瘍患者数

\begin{tabular}{cc|c|c|c}
\hline & & 男 & 女 & 計 \\
\hline \multirow{2}{*}{ 癌 } & 腫 & 10 & 2 & 12 \\
肉 & 腫 & 18 & 15 & 33 \\
\hline & 計 & 28 & 17 & 45
\end{tabular}

半を占めている.このらち, 頸部転移を示した 症例は 7 例 $(58 \%)$ であった。

表 2 扁桃癌の組織型別症例数

\begin{tabular}{c|c|c|c}
\hline & \multicolumn{2}{|c|}{ 症 } & \multicolumn{2}{c}{ 例 } & 数 \\
\hline & 男 & 女 & 計 \\
\hline 扁平上皮癌 & 8 & 2 & 10 \\
移行上皮癌 & 1 & 0 & 1 \\
リンパ上皮腫 & 1 & 0 & 1 \\
\hline 計 & 10 & 2 & 12
\end{tabular}

表 3 扁桃癌の病期別症例数

\begin{tabular}{|c|c|c|c|}
\hline \multirow{2}{*}{ Stage } & 症 & 例 & 数 \\
\hline & 男 & 女 & 計 \\
\hline I & 1 & 0 & 1 \\
\hline II & 2 & 0 & 2 \\
\hline III & 5 & 0 & 5 \\
\hline $\mathrm{N}$ & 2 & 2 & 4 \\
\hline 計 & 10 & 2 & 12 \\
\hline
\end{tabular}




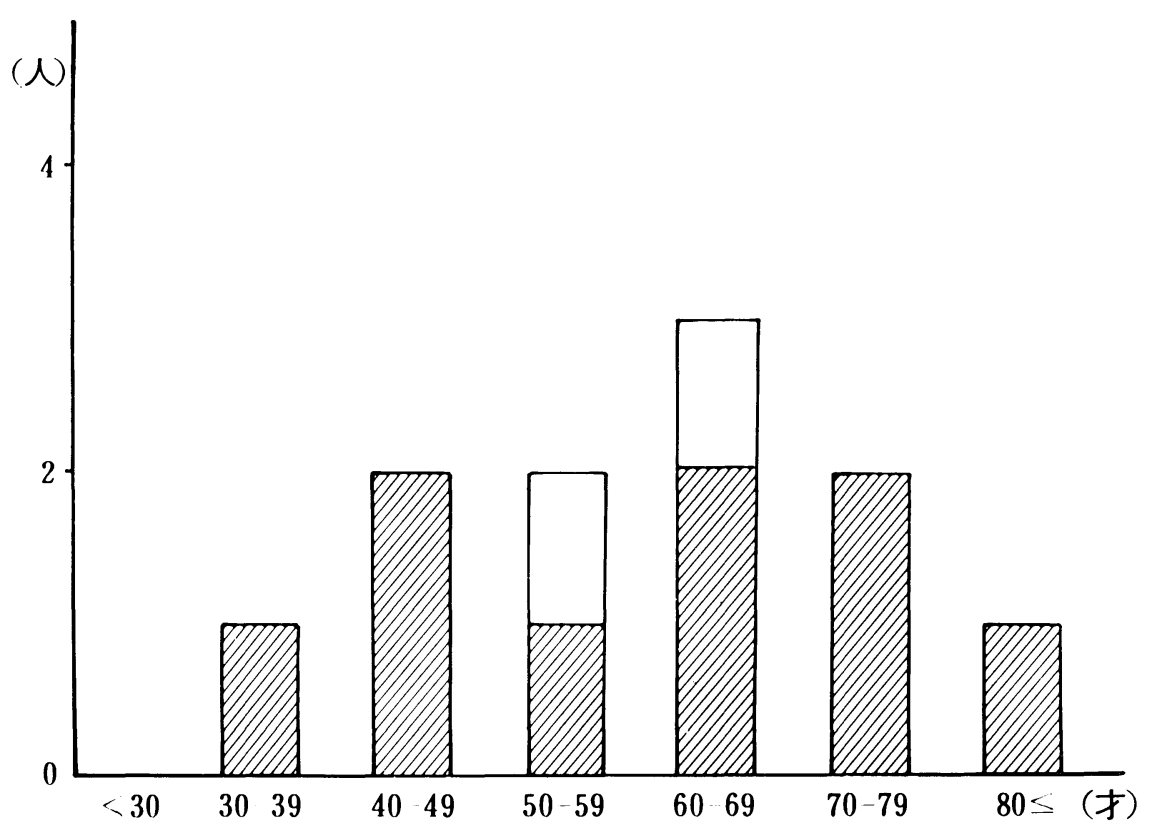

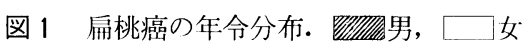

表 4 扁桃癌の主訴

\begin{tabular}{|c|c|c|}
\hline 訴 & 症 & 例 \\
\hline 頭 痛 & & 6 \\
\hline 咽 頭 異 和 感 & & 1 \\
\hline 䁰 部 腫 瘤 & & 3 \\
\hline 嚥 下 痛 & & 1 \\
\hline 耳＼cjkstart閉 & & 1 \\
\hline 計 & & 12 \\
\hline
\end{tabular}

患者の主訴についてみると, 咽頭痛が 6 例 (50\%)，頸部腫瘤が 3 例 $(25 \%)$ で計 $75 \%$ と大 半を占めた (表 4 ).

主訴発現より受診までの期間は，1力月以内 から 1 年以上まで平均的に分布しているが, Stage との関係をみると, Stage が進むにつれ て受診までの期間が長かった（表 5 ）.

治療に関しては，表 6 に示与如くで，于:術単 独例は 1 例もなく, 放射線及び化学療法を併用 したものが 3 例あった。この 3 例のらち， 1 例 は口蓋扁桃腫瘍摘出術を施行しているが（1964 年症例), 他の 2 例については, 原発巣にはお:
表 5 扇桃癌患者の来院までの期間

\begin{tabular}{|c|c|c|c|c|c|}
\hline 期間 … Stage & I & II & III & N & 計 \\
\hline 1 ケ月以内 & 0 & 1 & 1 & 1 & 3 \\
\hline 3 ケ月以内 & 0 & 0 & 3 & 0 & 3 \\
\hline 6 ヶ月以内 & 0 & 0 & 1 & 0 & 1 \\
\hline 1 年以内 & 0 & 0 & 0 & 1 & 1 \\
\hline 1 年以上 & 1 & 1 & 0 & 2 & 4 \\
\hline 計 & 1 & 2 & 5 & 4 & 12 \\
\hline
\end{tabular}

表 6 俩桃癌の治療

\begin{tabular}{l|cl}
\hline & 症例数 & \\
\hline $\mathrm{R}$ & 2 & \\
$\mathrm{R}+\mathrm{O}$ & 1 & \\
$\mathrm{R}+\mathrm{C}$ & 6 & \\
$\mathrm{R}+\mathrm{O}+\mathrm{C}$ & 3 & $\mathrm{R}:$ 放射線療法 \\
$\quad$ 計 & 12 & $\mathrm{O}:$ 手術療法 \\
& & $\mathrm{C}:$ 化学療法
\end{tabular}

術操作を加えずに，頸部手術のみに終ってい る. 放射線治療は 12 例全例に行い, この種の疾 病に対する治療法の主流をなしている。, 又, 最 近では， 6 例 $(50 \%)$ に, 放射線+化学㙩法を 
表 7 扁桃癌患者の粗生存率

\begin{tabular}{c|c|c}
\hline & 生存数/症例数 & $\%$ \\
\hline 1 年生存率 & $7 / 11$ & 64 \\
2 年生存率 & $2 / 10$ & 20 \\
3 年生存率 & $1 / 9$ & 11 \\
5 年生存率 & $0 / 7$ & 0
\end{tabular}

行い, 良好な結果を得ている.

癌腫の粗生存率は，1 年生存率が $64 \%$ である にもかかわらず， 2 年， 3 年，5年生存率は各 々 20\%，11\%，0\%と，全体に非常に予後の鱼 いことを示している（表 7 ). 病理組織型と粗 生存率との関係では，扁平上皮癌では，1年生 存率 $67 \%, 2$ 年生存率 $22 \%, 3$ 年生存率 $13 \%$ で，5年生存率は $0 \%$ であった。この様に 1 年 生存率に比較すると, 2 年, 3 年, 5 年生存率 は極端に悪い.移行上皮癌は 1 例であるが，未 だ経過が短い為， 2 年， 3 年，5年生存率を確 定することはできなかった。リンパ上皮腫は 1 例で，1 年未満に死亡しており，1 年生存率 0 \%である(表 8 ). 治療法別の粗生存率は表 9 に 示す如くで，放射線に化学療法を併用した群の 又が，1 年生存率 $80 \%, 2$ 年生存率 $50 \%, 3$ 年 生存率33\%で，他の群は，2年，3 年，5年生 存率は $0 \%$ であった。各群を 1 年生存率で比較 してみると, 放射線 + 手術群 $100 \%$, 放射線 + 化
表 8 病理組織型別にみた扁桃癌患者の粗生存率

\begin{tabular}{|c|c|c|c|c|}
\hline & $\begin{array}{c}1 \\
\text { 年存率 }\end{array}$ & $\begin{array}{c}2 \\
\text { 生存率 }\end{array}$ & $\begin{array}{c}3 \\
\text { 生存率 }\end{array}$ & $\begin{array}{c}5 \text { 年 } \\
\text { 生存率 }\end{array}$ \\
\hline 扁平上皮癌 & $\begin{array}{c}67 \% \\
(6 / 9)\end{array}$ & $\begin{array}{c}22 \% \\
(2 / 9)\end{array}$ & $\begin{array}{c}13 \% \\
(1 / 8)\end{array}$ & $\begin{array}{c}0 \% \\
(0 / 7)\end{array}$ \\
リンパ上行上皮癌 & $\begin{array}{c}100 \% \\
(1 / 1)\end{array}$ & - & - & - \\
\hline & $\begin{array}{c}0 \% \\
(0 / 1)\end{array}$ & $\begin{array}{c}0 \% \\
(0 / 1)\end{array}$ & $\begin{array}{c}0 \% \\
(0 / 1)\end{array}$ & $\begin{array}{c}0 \% \\
(0 / 1)\end{array}$
\end{tabular}

（）内は 生存数/症例数

表 9 治療法別にみた扁桃癌患者の粗生存率

\begin{tabular}{|c|c|c|c|c|}
\hline & $\begin{array}{l}1 \text { 年 } \\
\text { 生存率 }\end{array}$ & $\begin{array}{l}2 \text { 年 } \\
\text { 生存率 }\end{array}$ & $\begin{array}{l}3 \text { 年 } \\
\text { 生存率 }\end{array}$ & $\begin{array}{l}5 \text { 年 } \\
\text { 生存率 }\end{array}$ \\
\hline $\mathrm{R}$ & $\begin{array}{l}0 \% \\
(0 / 2)\end{array}$ & $\begin{array}{l}0 \% \\
(0 / 2)\end{array}$ & $\begin{array}{l}0 \% \\
(0 / 2)\end{array}$ & $\begin{array}{l}0 \% \\
(0 / 2)\end{array}$ \\
\hline $\mathrm{R}+\mathrm{O}$ & $\begin{array}{l}100 \% \\
(1 / 1)\end{array}$ & $\begin{array}{l}0 \% \\
(0 / 1)\end{array}$ & $\begin{array}{l}0 \% \\
(0 / 1)\end{array}$ & $\begin{array}{l}0 \% \\
(0 / 1)\end{array}$ \\
\hline $\mathrm{R}+\mathrm{C}$ & $\begin{array}{l}80 \% \\
(4 / 5)\end{array}$ & $\begin{array}{l}50 \% \\
(2 / 4)\end{array}$ & $\begin{array}{l}33 \% \\
(1 / 3)\end{array}$ & $\begin{array}{l}0 \% \\
(0 / 3)\end{array}$ \\
\hline $\mathrm{R}+\mathrm{O}+\mathrm{C}$ & $\begin{array}{l}33 \% \\
(1 / 3)\end{array}$ & $\begin{array}{l}0 \% \\
(0 / 3)\end{array}$ & $\begin{array}{l}0 \% \\
(0 / 3)\end{array}$ & $\begin{array}{l}0 \% \\
(0 / 2)\end{array}$ \\
\hline
\end{tabular}

$\mathrm{R}$ : 放射線療法 $\mathrm{O}$ : 手術療法 $\mathrm{C}$ : 化学療法 ( ) 内は 生存数/症例数

学療法群 $80 \%$, 放射線 + 手:術 +化学療法群 $33 \%$ で, 放射線+手術群が最も 1 年生存率良好に思 えるが, 症例数が 1 例なので, 比較の対象に入 れることができなかった。

\section{N 口蓋扁桃悪性リンパ腫について}

困 2 は扁桃悪性リンパ腫の年令別，性別の分 布を示し，60才台に最も大きいピークを持ち， 30才台に小さなピークを持つ二峰性を示し， 60 才以上が全体の50\%を占め, 比較的高齢者に多 発する傾向を持つが，全体では，癌腫よりも内 広い分布を示した。 又，男女差は表 1 に示した 様に，男子 $55 \%$ ，女子 $45 \%$ と差はなかった。

肉腫33例は全て悪性リンパ腫で, 病理組織学 的に分類すると，細網肉腫が31例 $(94 \%)$ と飞 の殆んどを占め, 次いで,リンパ肉腫 2 例 ( $6 \%$ ) で, Hodgikin 病は 1 例も認められなかった （表10）.
本報告ではこのよらな組織分類に従ったの で, 組織分類不能の症例及び悪性リンパ腫が疑 われる症例は対象から除外した。従って, 我々 の教室における頭頸部悪性リンパ腫についての 浜口ら ${ }^{9)}$ の報告と若干の例数の相違を生じてい る.

各症例の Stage 分類をみると, Stage I, 11例, Stage II, 20例であり, 両者を合わせる と，33例中 31 例 $94 \%$ を占める. Stage III は 2 例 ( $6 \%$ ) であったが, Stae N は 1 例もなかった (表11).しかし，これらには retrospective に 病気分類を行った症例を含んでおり，当教室で 


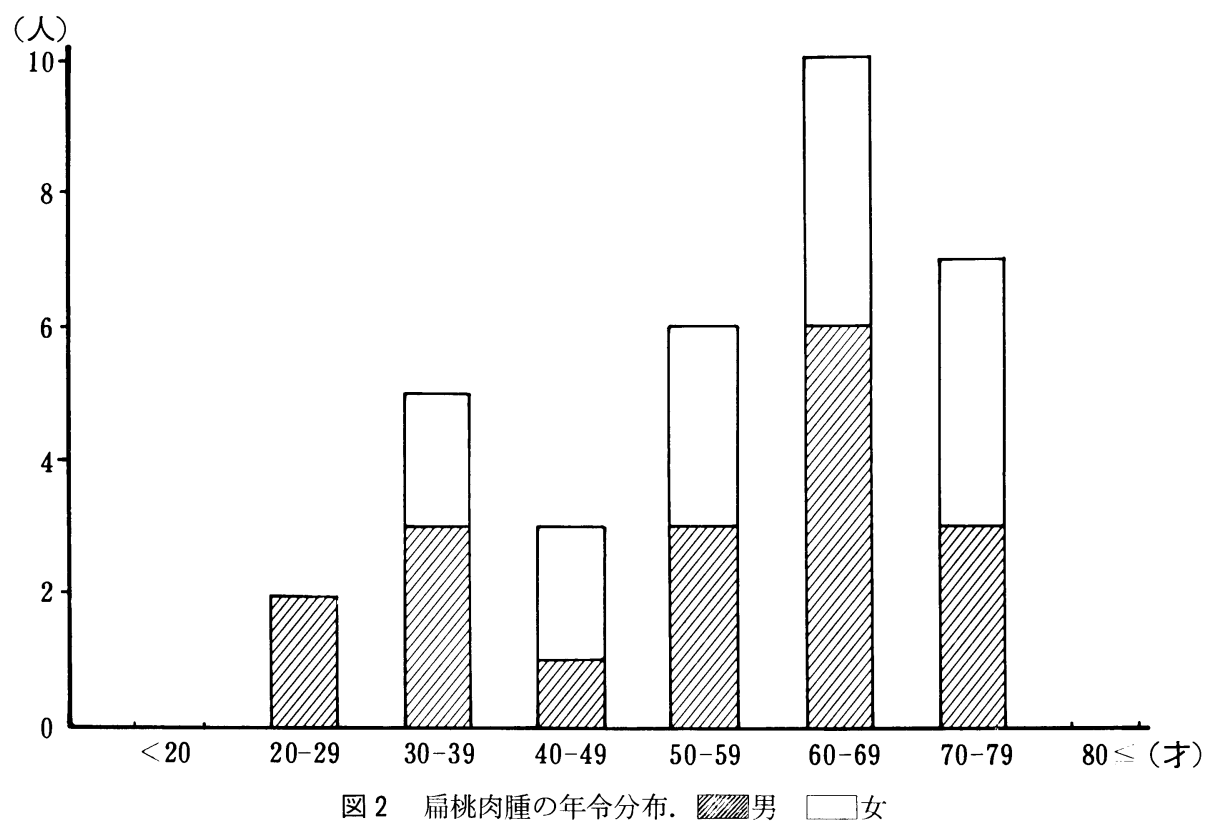

表10 扁桃肉腫の組織型別症例数

\begin{tabular}{c|c|c|c}
\hline & \multicolumn{2}{|c|}{ 症 } & 例 \\
\hline & 男 & 女 & 数 \\
\hline 細 網 肉 腫 & 17 & 14 & 31 \\
リンパ肉腫 & 1 & 1 & 2 \\
Hodgkin 病 & 0 & 0 & 0 \\
\hline 計 & 18 & 15 & 33
\end{tabular}

表11 扁桃悪性リンパ腫の病期別症例数

\begin{tabular}{|c|c|c|c|}
\hline \multirow{2}{*}{ Stage } & & 例 & \\
\hline & 男 & 女 & 計 \\
\hline I & 5 & 6 & 11 \\
\hline II & 13 & 7 & 20 \\
\hline III & 0 & 2 & 2 \\
\hline N & 0 & 0 & 0 \\
\hline 計 & 18 & 15 & 33 \\
\hline
\end{tabular}

は，1976年より routine に，Ga シンチ, リン パ管造影を行って病期分類を行っている. それ 故, 実際は Stage III, $\mathrm{N}$ 症例は多い可能性が あるものと推測される。
表12 扁桃悪性リンパ腫の主訴

\begin{tabular}{|c|c|c|c|}
\hline 訴 & 症 & 例 & 数 \\
\hline 咽 頭 痛 & & 10 & \\
\hline 咽頭異和感 & & 7 & \\
\hline 曣 下 痛 & & 2 & \\
\hline 曣 下 困 難 & & 2 & \\
\hline 府 桃 腫 瘤 & & 6 & \\
\hline 頸 部 腫 瘤 & & 4 & \\
\hline そ の 他 & & 2 & \\
\hline 計 & & 33 & \\
\hline
\end{tabular}

主訴は，咽頭痛が最も多く，33例中 10 例 $30 \%$ で, 癌腫の $50 \%$ と比較すると低值であるが, 逆 に, 咽頭異和感が 7 例 $21 \%$, 癌腫のそれに比 し著しく高値を示した. 頸部腫瘤又は局所の腫 瘤に気づき来院するものも多く，10例 $30 \%$ であ ったが，癌腫との差異は認められなかった。

又, 嚥下困難が 2 例あったことは注目に值す る(表12).

来院までの期間をみると， 6 力月以内に来院 する者が多く, 全体の $91 \%$ を占め, 中でも， 3 力月以内に来院した者は76\%と, 症状発現より 
表13 扁桃悪性リンパ腫患者の来院までの期間

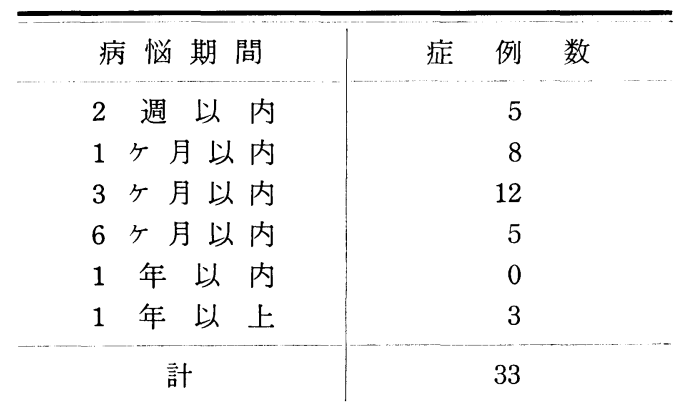

表14 扁桃悪性リンパ腫の治療

\begin{tabular}{|c|c|c|}
\hline & 症 & 例 数 \\
\hline $\mathrm{R}$ & & 14 \\
\hline $\mathrm{R}+\mathrm{O}$ & & 0 \\
\hline $\mathrm{R}+\mathrm{C}$ & & 18 \\
\hline $\mathrm{R}+\mathrm{O}+\mathrm{C}$ & & 1 \\
\hline 計 & & 33 \\
\hline
\end{tabular}

$\mathrm{R}$ ：放射線療法 $\mathrm{O}$ : 手術療法 $\mathrm{C}$ ：化学療法

表15 扁桃悪性リンパ腫の粗生存率

\begin{tabular}{l|c|c}
\hline & 生存数/症例数 & $\%$ \\
\hline 1 年 生 存率 & $14 / 31$ & 45 \\
2 年 生 存 率 & $12 / 30$ & 40 \\
3 年 生 存率 & $11 / 30$ & 37 \\
5 年 生 存率 & $5 / 23$ & 22
\end{tabular}

来院までの期間は比較的短い(表13)。又，来院 した者の中で, 明らかに頸部転移と思われる症 例は，22例67\%に認められた。

病側は, 右 20 例左 13 例と, 大差はないがやや 右側に多いようであった。

悪性リンパ腫の治療法は, 表14に示す様に, 手術療法は通常行なわれていなかった。ここに 示した手術症例は，1964年の Stage II の症例 で，扁桃腫瘍摘出術を施行したものであるが， 化学療法及び放射線潦法も併用している。 又, 全例に放射線療法を行い, 放射線単独例は14例 $41 \%$, 放射線＋化学療法例は 18 例 $55 \%$ であっ た. 化学療法を併用した症例は19例 $58 \%$ で，主 に, 代謝阻害剤, 副腎皮質ホルモンを使用し, 最近の症例には, VEMP 療法や MOPP 療法
表16 病期別にみた扁桃悪性リンパ腫の粗生存率

\begin{tabular}{c|c|c|c|c|}
\hline \multirow{2}{*}{ Stage } & $\begin{array}{c}1 \\
\text { 生存率 }\end{array}$ & $\begin{array}{c}2 \\
\text { 生存率 }\end{array}$ & $\begin{array}{c}3 \\
\text { 生存年 }\end{array}$ & $\begin{array}{c}5 \text { 年 } \\
\text { 生存率 }\end{array}$ \\
\cline { 2 - 4 } & $\begin{array}{c}73 \% \\
(8 / 11)\end{array}$ & $\begin{array}{c}73 \% \\
(8 / 11)\end{array}$ & $\begin{array}{c}64 \% \\
(7 / 11)\end{array}$ & $\begin{array}{c}57 \% \\
(4 / 7)\end{array}$ \\
\hline \multirow{3}{*}{ II } & $\begin{array}{c}22 \% \\
(4 / 18)\end{array}$ & $\begin{array}{c}18 \% \\
(3 / 17)\end{array}$ & $\begin{array}{c}18 \% \\
(3 / 17)\end{array}$ & $\begin{array}{c}14 \% \\
(2 / 14)\end{array}$ \\
\hline III & $\begin{array}{c}50 \% \\
(1 / 2)\end{array}$ & $\begin{array}{c}50 \% \\
(1 / 2)\end{array}$ & $\begin{array}{c}50 \% \\
(1 / 2)\end{array}$ & $\begin{array}{c}0 \% \\
(0 / 1)\end{array}$ \\
\hline
\end{tabular}

( ) 内は 生存数/症例数

表17 病理組織型別にみた扁桃覀性リンパ腫 の粗生存率

\begin{tabular}{|c|c|c|c|c|}
\hline & $\begin{array}{c}1 \text { 年 } \\
\text { 生存率 }\end{array}$ & $\begin{array}{l}2 \text { 年 } \\
\text { 生存率 }\end{array}$ & $\begin{array}{l}3 \text { 年 } \\
\text { 生存率 }\end{array}$ & $\begin{array}{l}5 \text { 年 } \\
\text { 生存率 }\end{array}$ \\
\hline 細 網 肉腫 & $\begin{array}{c}45 \% \\
(13 / 29)\end{array}$ & $\begin{array}{c}43 \% \\
(12 / 28)\end{array}$ & $\begin{array}{c}39 \% \\
(11 / 28)\end{array}$ & $\begin{array}{l}23 \% \\
(5 / 22)\end{array}$ \\
\hline リンパ肉腫 & $\begin{array}{l}50 \% \\
(1 / 2)\end{array}$ & $\begin{array}{l}0 \% \\
(0 / 2)\end{array}$ & $\begin{array}{l}0 \% \\
(0 / 2)\end{array}$ & $\begin{array}{l}0 \% \\
(0 / 1)\end{array}$ \\
\hline
\end{tabular}

（）内は 生存数/症例数

表18 治療法別にみた扁桃悪性リンパ腫の粗 生存率

\begin{tabular}{c|c|c|c|c|}
\hline & $\begin{array}{c}1 \text { 年 } \\
\text { 生存率 }\end{array}$ & $\begin{array}{c}2 \\
\text { 生存率 }\end{array}$ & $\begin{array}{c}3 \\
\text { 年生存率 }\end{array}$ & $\begin{array}{c}5 \\
\text { 生存率 }\end{array}$ \\
\cline { 2 - 4 } & $\begin{array}{c}14 \% \\
(2 / 14)\end{array}$ & $\begin{array}{c}8 \% \\
(1 / 13)\end{array}$ & $\begin{array}{c}8 \% \\
(1 / 13)\end{array}$ & $\begin{array}{c}8 \% \\
(1 / 12)\end{array}$ \\
\hline $\mathrm{R}+\mathrm{C}$ & $\begin{array}{c}69 \% \\
(11 / 16)\end{array}$ & $\begin{array}{c}56 \% \\
(9 / 16)\end{array}$ & $\begin{array}{c}50 \% \\
(8 / 16)\end{array}$ & $\begin{array}{c}40 \% \\
(4 / 10)\end{array}$ \\
\hline $\mathrm{R}+\mathrm{O}+\mathrm{C}$ & $\begin{array}{c}0 \% \\
(0 / 1)\end{array}$ & $\begin{array}{c}0 \% \\
(0 / 1)\end{array}$ & $\begin{array}{c}0 \% \\
(0 / 1)\end{array}$ & $\begin{array}{c}0 \% \\
(0 / 1)\end{array}$ \\
\hline
\end{tabular}

$\mathrm{R}$ ：放射線療法 $\mathrm{O}$ : 手術療法 $\mathrm{C}$ : 化学療法

（）内は 生存数/症例数

を用いている。

口蓋扁桃悪性リンパ腫の粗生存率をみると, 1 年, 2 年, 3 年生存率は, 各々 $45 \%, 40 \%$, $37 \%$ と有意な差は認められなかったが，5年生 存率は，前三者に比較すると極めて悪く， $22 \%$ であった。（表15). Stage 別の粗生存率をみる と, Stage I は, 5 年生存率が $57 \%$ とかなり 良好であるが, Stage II では，1年生存率が $22 \%$ あった. 又, Stage III は, Stage II に比し, 1 年, 2 年, 3 年生存率が良好であるが, 症例 が 2 例と少ないため, 比較するのは不可能であ 
る（表16），病理組織別の粗生存率では，細網 肉腫の 1 年, 2 年, 3 年生存率は, 各々 $45 \%$, $43 \% ， 39 \%$ であるが，5 年生存率は $23 \%$ と低值 を示した（表17）。治療法と粗生存率との関係 をみると，放射線単独療法では予後不良である

\section{V 考}

口蓋扁桃悪性腫瘍には, 癌腫, 悪性リンパ腫 などがあり，今回の報告では，癌腫と悪性リン パ腫の比率は，12例 $(27 \%): 33$ 例 $(73 \%)$ で あった。これは，本邦における諸家の報告 ${ }^{1334)}$ とほぼ一致をみたが，小河原ら ${ }^{2)}$ は，癌腫が約 40\%と比較的高い割合であったとしている。 又, 外国文献 ${ }^{11)}$ では, 肉腫よりも癌腫の方が多 いといら報告もあり，口蓋扁桃腫瘍では肉腫が 多いとは断言できないようである。

年令分布では, 癌腫では, 症例数は少ない が，癌年令に好発する傾向にあり，悪性リンパ 腫では，若年者から高令者まで比較的巾広い分 布を示し，一般にいわれる肉腫好発年令とほぼ 一致した。他の報告1224)101212 における年令分布 も，我々の報告と同様の傾向を示している.

男女比では，癌腫は殆んど男性に発生をみ， 悪性リンパ腫ではやや男性に多かった。河辺 ${ }^{10)}$ は，癌腫の男女比はほぼ同数であるとしている が，その他多くの報告では，我々とほぼ同様の 傾向をみた ${ }^{1224)}$. 扁桃癌患者には喫煙者が多く, 従って，タバコが扁桃癌の原因の一つと考えら れ，また男性に好発する理由でもあるとして重 視する傾向がみられる110)11.

病理組織型では，癌腫は扁平上皮癌が殆んぞ で，肉腫は全例悪性リンパ腫であり，そのら ち，細網肉腫が大半を占めた。諸家の報告にお いて，扇平上皮癌の癌腫に対する割合及び細網 肉腫の肉腫に対する割合をみると，小田 ${ }^{1)}$ は各 々 $75 \%$ 及び $85 \%$ ，小河原ら 2 は $100 \%$ 及び $53 \%$ ， 久保3) は $86 \%$ 及 $106 \%$, 栗田口4) らは $58 \%$ 及び $84 \%$ ，河辺 ${ }^{10)}$ は $86 \%$ 及び $88 \%$ としており，我々 の83\%及び94\%とほぼ同様である。

Stage 分類では, 癌腫では, Stage III, IV
が，放射線療法に化学療法を併用すると， 1 年 生存率 $69 \%, 2$ 年生存率 $56 \% ， 3$ 年生存率 $50 \%$ でかなり良く，5年生存率でも $40 \%$ を示した (表18).

\section{察}

が殆んぞで，覀性リンパ腫では， Stage II が 最も多く, 両者とも頸部転移の早い事を物語っ ている，解剖学的にみると，扁桃りンパ組織で 産生されたりンパ流は, 甬桃周囲輸出りンパ管 を経て頸部リンパ節に至り，右リンパ本管又は 胸管に入るが，この扁桃及びその周囲組織のリ ンパ流は豊富であり，このため，阴桃悪性腫瘍 は早期に頸部転移をきたすと考えられる。墨性 リンパ腫に Stage II の症例が多いのは, 頸部 䎐移が早く, 頸部腫瘤に気づいて初めて来院す る者が比較的多い（12\%）ことなどによると思 われる，尚，現在当科の治療方針として，悪性 リンパ腫は Stage II までを担当し，化学療法 が主体となる Stage III, $\mathrm{N}$ 症例は内科との協 力の下に治療を行っている．初診時既に頸部転 移を認めた症例の割合は，癌腫では $58 \%$ ，悪性 リンパ腫では $67 \%$ であり, それらの 3 年生存辩 は，癌腫では20\%，悪性リンパ腫では $21 \%$ であ った．諸家の報告1) 6)1013)では，初診時頸部転 移を認めた症例は，癌腫では，49-100\%，肉 腫では， $72-88 \%$ と，両者ともおよそ70-80\% 程度であり，我々の報告同様高い值を示してい る。それらの 3 年生存率をみると, 癌腫では, Quenelle らは5) $50 \%$, Wang ${ }^{6)}$ は $34.8 \%$, 河 辺 ${ }^{10)}$ は $50 \%$ ，悪性リンパ腫では，河辺 ${ }^{100} は 10.5$ $\%$, 藤谷ら ${ }^{13)}$ は $35 \%$ としおり, 癌腫では我々 より良好な成績を示すものが多いが，悪性りン 八腫の予後は我々の報告を含め, 余り良好とは いえない。

患者の主訴に関しては, 一般的に, 癌腫, 悪 性リンパ腫とも, 咽頭痛, 咽頭異和感など咽頭 部に異常を訴えることが多く，悪性リンパ腫で は, 癌腫に比し, 咽頭異和感を訴える者が多 
い. 又, 燕下困難を訴える例は，悪性リンパ腫 のみに認められた。これら疼痛を伴わない症状 は, 悪性リンパ腫のひとつの特徵といえる. 又, 両者とも, 頸部腫瘤を主訴として来院する ことが多く, ここでも, 頸部転移が比較的早期 に起こることを反映する現象がみられた。

発病から来院までの期間は, 癌腫, 悪性リン 八腫とも比較的早く, 粟田口ら ${ }^{4)}$ は, 局所症状 の多いこと，患者自身が観察可能な部位である ことなどが受診を早める要因になるとしてい る，我々の例でも，悪性リンパ腫において，局 所の腫瘤に気づいて来院した者が 6 例（18\%） 認められた。しかし一方, Wang ${ }^{6)}$ は，扁桃癌 において，あまり急性炎症症状を伴わないため 来院が遅れることを指摘している. 我々の例で も, 癌腫は, 悪性リンパ腫に比し, 来院までの 期間がやや長かった（表 4，12）.

我々の教室に於いて, 徧桃悪性りンパ腫の頭 頸部悪性りンパ腫に占める位置をみる為, 本報 告と浜口ら ${ }^{9)}$ の報告を比較した。浜口ら ${ }^{9)}$ は, 頭頸部悪性リンパ腫では, 男女比は, 全症例95 例のうち，男子59例 (62\%) : 女子 36 例( $38 \%)$, 組織別分類では，細網肉腫81例 $(85 \%)$, リン 八内肉腫10例 $(11 \%)$, Hodgikin 病 3 例 ( $3 \%$ ) としており，それぞれ，陑桃悪性リンパ腫の分 布とほぼ同様であった。一方，年令分布では， 50一79才に62例 $(66 \%)$ が集中する一峰性の分 布であり，扁桃悪性りンパ腫における二峰性の ピーク（図 2) は示さず, Stage 分類では, Stage I は28例 (29.5\%), は47例 (49.5\%), Stage I は14例 $(14.7 \%)$, Stage N は 6 例 (6.3\%) と, 扁桃悪性リンパ腫に比し, Stage III, N 症例が多かった。 又, 我々の教室では, 扁桃悪性リンパ腫の頭頸部悪性リンパ腫に対す る割合は $49.5 \%$ で第 1 位 ${ }^{9)}$ であり, Tikka ら ${ }^{12)}$ も, 頭頸部細網肉腫87例中扁桃原発のものは 20 例 $(23 \%)$ で第 1 位であるとしており，頭頸部 領域に於いて，陑桃は悪性りンパ腫の好発部位。 といえよう，予後を比較すると，頭頸部全体で は, 1 年, 3 年, 5 年生存率がそれぞれ $51.7 \%$,
$35.6 \%, 31.6 \%$ と扁桃と殆んど一致してお り, Stage 別生存率でも，扁桃同様 Stage I, III良好な成績を示している ${ }^{9}$.

一方, 頭頸部領域のうち, 悪性リンパ腫の発 生を比較的多くみる上咽頭の場合と比較する と, 我々の教室では, 村井ら ${ }^{14)}$ は, 上咽頭悪性 リンパ腫では, 男女比は 2.4:1 と男性に多く, 年令分布は，60才代と20才代の 2 つのピークを 持つ二峰性分布であったとしており，いずれも 扁桃の場合と同様の傾向を示した。組織別分類

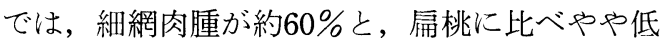
值だが最も多く認められたとしているが, Stage 分類では, Stage III 以上の症例が74.5\% と大半を占め, 扁桃とは全く異った結果を示し た．治療法は放射線療法が主体である事は扁桃 の場合と同じであるが，予後では，Stage III， $\mathrm{N}$ の症例が多いにもかかわらず， 5 年生存率 $45.7 \%$ とかなり良好であり, 扁桃悪性リンパ腫 に比べ，例えば，放射線感受性に何らかの差が あるのではないかと想像される。

扁桃悪性腫瘍の治療法には，手術，放射線及 び化学療法があるが，我々は，悪性リンパ腫は 勿論, 癌腫も放射線感受性が高いと考え, 放射 線療法を主体とした治療を行った。手術を行っ た症例では, 扁桃腫瘍摘出施行の 2 例（癌腫 1 例，悪性リンパ腫 1 例）はともに 1 年以内に死 亡し, 頸部手術施行の癌腫 3 例も， 2 例は 1 年 以上生存したものの， 2 年生存率は $0 \%$ であっ た。

一方，扁桃癌に対しては，手術療法を用いる 者は比較的多く, Whicker $5^{15)}$ は, 手術療法 が唯一の方法であるとし，2 年生存率 $48 \%$ の成 績を得，再発率は，放射線単独群の $49 \%$ に対 し，19\%であったとしている. Barr ら Stage I, II には手術単独で, Stage III, N には手術と術後照射を行らのが良いとしてい る. Quenelle ら5) は, 5000 rad の術前照射と 手術を行い， $58 \%$ の 2 年生存率を得，特に， $\mathrm{T}_{3}$ 症例では $60 \%$ の良好な成績を得たとしている. 又, 小田 ${ }^{1)}$, 久保 ${ }^{3)}$ は, 頸部廓清術を重視し, 
特に久保 ${ }^{3)}$ は, 頸部転移が組織学的転移を含め ると非常に高率であり, 頸部にのみ転移がとど まっている時期に㹁清すれば全身転移が防止で きる可能性があるとの考えに基づき，原発巣に 手術適応がない場合でも, リンパ節腫大の有無 にかかわらず頸部産清術の必要性を主張してい る. 一方, 小河原 $5^{2)}$, 粟田口 $5^{4)}$, 河辺 ${ }^{10)}$, Wang ${ }^{6)}$ は, 扁桃癌に対して放射線療法を主体 とした治療を主張し, 中でも, 粟田口ら゙)は, 5 年生存率 $37.5 \%$ の成績を得ている。 その他, 久保 ${ }^{3)}$, 佐藤 ${ }^{17)}$ は, 広範進展例には動注を併用 することをすすめている。

扁桃悪性リンパ腫に対しては, 放射線療法が 主流であり, 小田 ${ }^{1)}$, 河辺 ${ }^{10)}$ は, 手術は禁忌又 は最後の手段であるとしている.しかし，久 保 ${ }^{3)}$ は1969年に悪性リンパ腫に対しても, 頸部 廓清術を併用しつつ, 原発巣に手術を加える事 により，5年生存率 $63.6 \%$ の良好な結果を得た としている。我々は, 放射線療法を主流とし, 前述の 1 例のみに手術を施行した。化学療法の

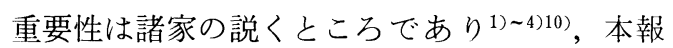
告でも58\%の症例に化学療法を併用し, 前述の 如く, 化学療法併用群では良好な結果を示し た. 従来, 化学療法は, 主に Stage III 以上の 症例に対し単独に用いていたが，最近では，

Stage I, II の症例にも放射線療法と併用した 事が，良好な予後を得る一因となったと考えら れる。しかし, 抗癌剤の副作用は重要な問題で あり, Kaplan ${ }^{18)}$ は, Stage I, II の Hodgikin 病に対する nitrogen mustard やアルキル化剂 の使用については, 余り効果のない事, 強い 副作用を考台わせ, 否定的立場をとってい る。抗癌剤の副作用でしばしば問題となるのは 骨髄障害であり，これは放射線との併用により 一層增強される.しかし, 最近は vinca alkaloid の出現により,この問題もある程度の改善を み，木村ら ${ }^{19}$ は, vinca alkaloid を使用した多 剂併用療法を用い, 良好な成績を報告してい

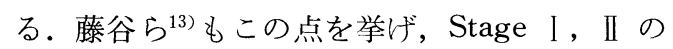
症例に化学療法を併用する姿勢を示している.
表19扁桃癌に対する放射線療法と粗生存率

\begin{tabular}{|c|c|c|c|c|c|}
\hline $\begin{array}{l}\text { 照射線量 } \\
\text { (rad) }\end{array}$ & 症例数 & $\begin{array}{c}1 \text { 年 } \\
\text { 生存率 }\end{array}$ & $\begin{array}{l}2 \text { 年 } \\
\text { 生存率 }\end{array}$ & $\begin{array}{c}3 \text { 年 } \\
\text { 生存率 }\end{array}$ & $\begin{array}{l}5 \text { 年 } \\
\text { 生存率 }\end{array}$ \\
\hline $4000 \leqq$ & 1 & $\begin{array}{r}0 \% \\
(0 / 1)\end{array}$ & $\begin{array}{l}0 \% \\
(0 / 1)\end{array}$ & $\begin{array}{l}0 \% \\
(0 / 1)\end{array}$ & $\begin{array}{r}0 \% \\
(0 / 1)\end{array}$ \\
\hline $5000 \leqq$ & 1 & $\begin{array}{l}100 \% \\
(1 / 1)\end{array}$ & $\begin{array}{l}100 \% \\
(1 / 1)\end{array}$ & $\begin{array}{l}100 \% \\
(1 / 1)\end{array}$ & - \\
\hline $6000 \leqq$ & 3 & $\begin{array}{l}100 \% \\
(3 / 3)\end{array}$ & $\begin{array}{l}33 \% \\
(1 / 3)\end{array}$ & $\begin{array}{r}0 \% \\
(0 / 2)\end{array}$ & $\begin{array}{r}0 \% \\
(0 / 1)\end{array}$ \\
\hline $7000 \leqq$ & 2 & $\begin{array}{l}50 \% \\
(1 / 2)\end{array}$ & $\begin{array}{l}0 \% \\
(0 / 1)\end{array}$ & $\begin{array}{l}0 \% \\
(0 / 1)\end{array}$ & $\begin{array}{r}0 \% \\
(0 / 1) \\
\end{array}$ \\
\hline $8000 \leqq$ & 1 & $\begin{array}{l}100 \% \\
(1 / 1)\end{array}$ & $\begin{array}{l}0 \% \\
(0 / 1)\end{array}$ & $\begin{array}{l}0 \% \\
(0 / 1)\end{array}$ & $\begin{array}{l}0 \% \\
(0 / 1)\end{array}$ \\
\hline $9000 \leqq$ & 3 & $\begin{array}{l}33 \% \\
(1 / 3)\end{array}$ & $\begin{array}{r}0 \% \\
(0 / 3)\end{array}$ & $\begin{array}{c}0 \% \\
(0 / 3)\end{array}$ & $\begin{array}{c}0 \% \\
(0 / 3)\end{array}$ \\
\hline
\end{tabular}

( ) 内は 生存数/症例数

表20扁桃悪性リンパ腫に対する放射線療法 と粗生存率

\begin{tabular}{c|c|c|c|c|c|}
\hline $\begin{array}{c}\text { 照射線量 } \\
\text { (rad 症例数 }\end{array}$ & $\begin{array}{c}1 \\
\text { 生存率 }\end{array}$ & $\begin{array}{c}2 \\
\text { 生存率 }\end{array}$ & $\begin{array}{c}3 \\
\text { 生存率 }\end{array}$ & $\begin{array}{c}5 \text { 年 } \\
\text { 生存率 }\end{array}$ \\
\hline $2000 \leqq$ & 3 & $\begin{array}{c}33 \% \\
(1 / 3)\end{array}$ & $\begin{array}{c}33 \% \\
(1 / 3)\end{array}$ & $\begin{array}{c}33 \% \\
(1 / 3)\end{array}$ & $\begin{array}{c}33 \% \\
(1 / 3)\end{array}$ \\
\hline $3000 \leqq$ & 5 & $\begin{array}{c}60 \% \\
(3 / 5)\end{array}$ & $\begin{array}{c}40 \% \\
(2 / 5)\end{array}$ & $\begin{array}{c}40 \% \\
(2 / 5)\end{array}$ & $\begin{array}{c}40 \% \\
(2 / 5)\end{array}$ \\
\hline $4000 \leqq$ & 8 & $\begin{array}{c}38 \% \\
(3 / 8)\end{array}$ & $\begin{array}{c}38 \% \\
(3 / 8)\end{array}$ & $\begin{array}{c}38 \% \\
(3 / 8)\end{array}$ & $\begin{array}{c}0 \% \\
(0 / 4)\end{array}$ \\
\hline $5000 \leqq$ & 8 & $\begin{array}{c}57 \% \\
(4 / 7)\end{array}$ & $\begin{array}{c}50 \% \\
(3 / 6)\end{array}$ & $\begin{array}{c}50 \% \\
(3 / 6)\end{array}$ & $\begin{array}{c}20 \% \\
(1 / 5)\end{array}$ \\
\hline $6000 \leqq$ & 1 & $\begin{array}{c}0 \% \\
(0 / 1)\end{array}$ & $\begin{array}{c}0 \% \\
(0 / 1)\end{array}$ & $\begin{array}{c}0 \% \\
(0 / 1)\end{array}$ & $\begin{array}{c}0 \% \\
(0 / 1)\end{array}$ \\
\hline $7000 \leqq$ & 1 & $\begin{array}{c}0 \% \\
(0 / 1)\end{array}$ & $\begin{array}{c}0 \% \\
(0 / 1)\end{array}$ & $\begin{array}{c}0 \% \\
(0 / 1)\end{array}$ & $\begin{array}{c}0 \% \\
(0 / 1)\end{array}$ \\
\hline $8000 \leqq$ & 1 & $\begin{array}{c}100 \% \\
(1 / 1)\end{array}$ & $\begin{array}{c}100 \% \\
(1 / 1)\end{array}$ & $\begin{array}{c}100 \% \\
(1 / 1)\end{array}$ & $\begin{array}{c}100 \% \\
(1 / 1)\end{array}$ \\
\hline $9000 \leqq$ & 4 & $\begin{array}{c}25 \% \\
(1 / 4)\end{array}$ & $\begin{array}{c}25 \% \\
(1 / 4)\end{array}$ & $\begin{array}{l}25 \% \\
(1 / 4)\end{array}$ & $\begin{array}{c}25 \% \\
(1 / 4)\end{array}$ \\
\hline
\end{tabular}

\section{( ) 内は 生存数/症例数}

放射線療法は, 癌腫, 悪性リンパ腫の両者に 用いられるが，その施行に際しては，適正線量 が問題となる。癌腫では, 滋賀ら ${ }^{201}$ は $6000 \mathrm{rad}$ 以上照射群に予後良好な例が多かったとし，悪

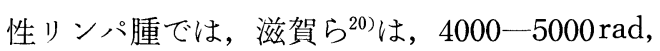
藤谷ら ${ }^{13)}$ は $3500 \mathrm{rad}$ 以上, 北畠ら ${ }^{21)}$ は $4000 \mathrm{rad}$, Tikka ら ${ }^{12}$ は 4000-5000 rad が適当であろう 
と結論している，又，Kaplan ${ }^{18)}$ は，Hodgikin 病に対しては 3500-4000 $\mathrm{rad}$ が適当であると している，そこで，我々の症例で，照射線量之 予後の関係をみてみると，表19及び20の様にな る，放射線単独療法は少ないので即断はできな いが，癌腫では，5000-7000 rad 照射群に，悪 性リンパ腫では，4000-6000 rad 照射群に比較 的予後良好な結果をみ, 前述の諸報告(2)1318)20)21) とほぼ同様の傾向を示している。

今回の報告では，癌腫，悪性リンパ腫とも，
余り予後は良好でなく，特に癌腫の予後は不良 である，癌腫症例には高令者及び Stage の進 んだ者が多く, 又, 詳細は省いたが, 肝硬変等 の致命的な合併症を持った症例も少なくなく， これらも予後を低下させる一因であろらが，手 術療法も含め, 種々の療法について検討した い. 悪性リンパ腫については, 前述の如く, Stage I, II の症例にも, 積極的に化学療法を 併用し，予後に及ぼす影響について検討したい と考える。

\section{VI 結 語}

三重大学医学部耳鼻咽喉科学教室における過去20年間の口蓋扁桃悪性腫瘍45例について統計的観 察を行った。

1） 45 例のらち, 癌腫は12例 $(27 \%)$, 肉腫は33例（73\%）で，肉腫は全例悪性リンパ腫であっ た.

2）男女比では，癌腫では男子10例女子 2 例と圧倒的に男子に多く，悪性リンパ腫では男子18例 女子15例とあまり性差はなかった。

3）年令分布では, 癌腫では癌年令に好発する傾向にあり, 悪性りンパ腫では60才台に大きなピ ークと30才台に小さなピークを持つ二峰性を示した.

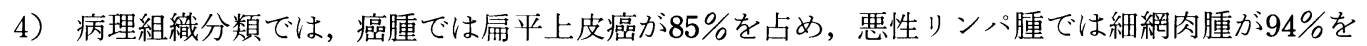
占めた。

5） Stage 分類では，癌腫では Stage I ，II を合わせても 3 例（25\%）で, Stage III, N が 9 例 $(75 \%)$ と進行例が多く，悪性リンパ腫では Stage I , II を合わせると31例（94\%）を占め, Stage III は 2 例 $(6 \%$ ) で, Stage N は 1 例もなく, 早期例が多かったものの, Stage II が20例 (61\%) と最も多く, 癌腫, 悪性リンパ腫ともに, 早期転移の起こることを示した.

6）主訴では, 癌腫及び悪性リンパ腫とも咽頭痛が最も多かったが, 悪性リンパ腫では咽頭異和 感が比較的多かった。頸部腫瘤に気づき来院する者は，癌腫では 3 例 $(25 \%)$ ，悪性リンパ腫では 4 例 $(12 \%)$ であった。

7）治療法では, 癌腫, 悪性リンパ腫とも放射線療法を主体とした，化学療法を併用した例は， 癌腫では 9 例 $(75 \%)$, 悪性リンパ腫では19例（58\%）であった.

8）粗生存率では, 癌腫では， 1 年生存率は $64 \% ， 2$ 年生存率は $20 \%, 3$ 年生存率は, 5 年生存 率は $0 \%$ と非常に悪く，悪性リンパ腫では，1 年，2 年，3 年生存率はそれぞれ，45\%，40\%，37 \%であったが， 5 年生存率は $22 \%$ であった。悪性リンパ腫の Stage 別粗生存率では, Stage I の 5 年生存率は $75 \%$, Stage II では 1 年生存率が $22 \%$ であった。治療別の予後では, 癌腫では, 放 射線＋化学療法群のみが 1 年生存率 $80 \%, 2$ 年生存率 $50 \%, 3$ 年生存率 $33 \%$ で，他の群は 2 年， 3 年, 5 年生存率は $0 \%$ であり, 悪性リンパ腫では, 放射線十化学療法群は 1 年生存率 $69 \%, 2$ 年生 存率 $56 \%, 3$ 年生存率 $50 \%, 5$ 年生存率 $40 \%$ であり, 今後, Stage I, II の症例にも化学療法を併 用したいと考える。

9）放射線療法は，口蓋扁桃の癌腫，墨性リンパ腫に対する基本的な治療法であるが，癌腫では 
5000-7000 rad 照射，悪性リンパ腫では 4000-6000 rad 照射に予後の比較的良好な症例が多かっ た。

\section{文献}

1）小田雅義：扁桃悪性腫煌の集計的観察. 耳鼻臨床 $56: 497 \sim 501,1963$.

2）小河原昇, 他：扁桃悪性腫湯の臨床的観察（会). 日耳鼻 $81 ： 1191 \sim 1192,1978$.

3）久保隆一：中咽頭覀性腫場の治療, 特に口蓋扁桃 悪性腫瘍の治療について。 日耳鼻 $72: 589 \sim 593$, 1969.

4）粟田口省吾, 井上哲：口蓋扁桃の悪性腫煬. 日耳 鼻 $74: 1252 \sim 1262,1972$.

5) Quenelle DJ, et al : Tonsil carcinoma-treatment results. Laryngoscope $89: 1842 \sim 1846$, 1979.

6) Wang CC : Management and prognosis of squamous cell carcinoma of the tonsillar region. Radiology $104: 667 \sim 671,1972$.

7) UICC : TNM. 3rd ed, Genera, 1978.

8) Carbone PP, et al: Report of the committee on Hodgikin's disease staging classification. Cancer Res $31: 1860 \sim 1861,1971$.

9）浜口幸吉, 他：悪性リンパ腫95例の臨床的検討. 耳鼻臨床 $74 ： 1054 \sim 1063 ， 1981$.

10）河辺義孝：扁桃悪性腫瘍の治療成績について。耳 鼻臨床 $58: 610 \sim 620,1965$.

11) Ward NO, et al : Carcinoma of the tonsil. Am J Surg $116:$ 487 490, 1968.

12) Tikka U, Malmio $\mathrm{K}$ : Clinical and radiotherapeutic aspects of reticulum cell sarcoma.
Acta Radiol [Ther] $8: 459 \sim 470,1969$.

13）藤谷哲造, 他：口蓋扁桃細網肉腫の統計的観察. 耳鼻臨床 $67: 711 \sim 718,1974$.

14）村井須美子, 他：上咽頭悪性腫瘍の臨床的観察. 耳鼻臨床 $74: 980 \sim 991,1981$.

15) Whicker $\mathrm{JH}$, et al : Surgical treatment of squamous cell carcinoma of the tonsil. Laryngoscope $84: 90 \sim 97,1974$.

16) Barrs DM, et al:Squamous cell carcinoma of the tonsil and tongue-base region. Arch Otolaryngol $105: 479 \sim 485,1979$.

17）佐藤靖雄：放射線科とのチームワークによる頭頸 部悪性腫瘍の治療法について。耳鼻 19:259〜 348, 1973.

18) Kaplan HS : The radical radiotherapy of regionally localized Hodgikin's disease. Radiol 78 : $553 \sim 569,1962$.

19）木村禧代二, 他：悪性りンパ腫の化学療法. 最新 医学 $34 ： 816 \sim 824,1969$.

20）滋賀秀壮, 水谷淳子：扁桃腫瘍について（抄). 第21回頭頸部腫瘍研究会：58, 1972.

21）北畠隆, 他：悪性リンパ腫の放射線治療. 臨放 $17: 859 \sim 868,1972$.

$\left(\begin{array}{l}\text { 別刷請求先: 西岡博之 } \\ \text { T514 } \\ \text { 三重大学医学部耳梠耳咽喉科学教室 }\end{array}\right)$ 